\title{
The Quotidian of Italian Immigration in La Staffetta Rio- Grandense According to Michel Maffesoli
}

\author{
Beatriz DORNELLES*, Ph. D.
}

Brazil

\author{
*Corresponding Author: Beatriz DORNELLES*,Ph. D., Brazil
}

\begin{abstract}
This work aims to highlight the role played by communication processes and their impact in daily life, through the Italian written Brazilian press, between the 19th and 20th centuries, the strongest period of Italian immigration in Brazil. In emphasizing the importance of quotidian experience present in the editions of the Rio Grande do Sul's newspaperLa Staffetta Rio-Grandense, and the relationship with its readers. We analyzed some texts in the light of Michel Maffesoli's assumptions, in Post-Modernity. By dialoguing with the similarities in the formation of immigrant cultural identity and social insertion, it was possible to understand the importance of journalism as a protagonist in the construction of social practices.
\end{abstract}

Key words: Communication; Italian press; Journalism; Daily Journalism; Sociology.

\section{INTRODUCTION}

This study analyzes how the Italian immigrant placement process happened, in the state of Rio Grande do Sul, how the mass communication media helped in the construction of a new life, in a different reality from the one they knew. Identifies how this process took place, having a newspaper in this study La Staffetta Rio-Grandense - as an object of study in society's everyday life, and responsible for forging significant values throughout civilizations.

The choice of the newspaper was due to its importance as a means of communication, mainly because, in the period of analysis, cinema, radio, television, and other communication tools were not available.

The arrival of Italian immigrants was in the mid-19th century and they had contact with the gauchos ${ }^{11}$ community reality at their arrival. These immigrants were located in peripheral areas of some cities, mostly, in the condition of a farmhand in large plantations with socio-cultural habits quite different from their motherland. The scenario was one of the difficulties, aggravated by the imposition of living with people who did not speak their mother tongue and were unaware of their prior customs.

The arrival of Italians in that period is one of the largest migratory processes in Brazilian history as well as other countries such as the United States, Argentina, Uruguay, and Venezuela, in order of representativeness. In Brazil, some measures were taken to ensure a smooth process, with significant financial resources allocated to the entire operation. However, effectiveness and human relationships are two operations that do not necessarily go together as the first is based on commercial agreements and the second, on human and social relationships.

In this sense, it is important to clarify that human relations are based on their capacity for social construction, respecting their geographical, cultural, affective, and technological variations.

\footnotetext{
${ }^{1}$ Demonym to describe those born in the Brazilian state of Rio Grande do Sul. The gauchos from the Pampas region are descendants of a mixture of Europeans and Indians with important peculiarities. Their European ancestors are mainly Spanish, different from the rest of Brazilians who descent from Portugueses. The Pampas land region was disputed between Portugal and Spain for many years and was only given to Portugal domain in 1750. However, the war for the lands assigned by the Tordesillas' Treaty did not end until the late 19th century. This particular region of Brazil was not influenced by the significant ethnic Azorean, German and Italian immigration like other regions of Rio Grande do Sul. Anthropologist Darcy Ribeiro wrote that the gauchos 'arise from the ethnic transfiguration of the mixed-race populations of Spanish and Lusitanians with Guarani women'. As a result of ethnic miscegenation, Portuguese spoken in the Pampas has many Spanish, indigenous, and some African expressions as well the Spanish accent. Available at: https://pt.wikipedia.org/wiki/Ga\%C3\% BAcho. Accessed on: 3 May 2020.
} 


\section{RESEARCH METHOD}

Our research starts from the interpretative analysis of texts published in Italian on the pages of the newspaperLa Staffetta Rio-Grandense ${ }^{2}$. To highlight the importance of the daily experience of Italian immigration, initially, as a form of belonging and social recognition and, later, for its cultural contribution, left as a legacy for the gaucho community.

From a rich universe of regional publications, the choice to narrow the research by concentrating the analysis in the newspaperLa Staffetta Rio-Grandense is due to its editorial line and its activity period, as one of the most representative press vehicles in the Italian immigration region in the Rio Grande do Sul. For this purpose, the content analysis as a qualitative research technique was used. The reading of 49 editions $^{3}$ referring to the period from January 7 to December 30, 1925, represents the totality of editions of that year ${ }^{4}$. that made a research corpus of 12 editions, one for each month, in alternating weeks.

A textual analysis following the principles evidenced by Bardin (1977), was performed, according to their representativeness, homogeneity, and pertinence. The aim, through qualitative analysis, was to describe the content of each message "that allows the inference of knowledge related to the conditions of production/reception (inferred variables) of these messages" (BARDIN, 1977, p. 42). The proposed clipping describes published material in the newspaper, which is why it will be possible to understand the real meaning of the daily relationship of the community with its newspaper.

La Staffetta (affectionately called by the immigrant) has become a media capable of not only informing, a primary function of the press but of mediating and structuring actions relevant to its citizenship. It was from the articles published on its pages that the reader newly arrived from Italy became aware of his rights and duties, in addition to information sessions on health, job opportunities, and news from Italy.

\section{LITERATURE REVIEW}

Throughout the article, we describe and analyze part of the published content, addressed to the Italian settler, considering the historical context of the time, based on the theoretical framework about the quotidian, based on the French sociologist Michel Maffesoli's theory ${ }^{5}$. His ideas and assumptions are the basis for studies on the quotidian and imaginary by safeguarding a less rational and technical view, more human and inclusive, where the subject no longer has a function, but a role within the group.

The intention of adopting some of his studies in the context of Comprehensive Sociology (PostModernity) in confrontation with the community experience of Italian immigrants in Brazil (19th 20th centuries) was due to his observations on the social relationship based on everyday wisdom present in the art of making joint knowledge. A way to contextualize the plural knowledge arising from the collective feeling of belonging where, according to the author, "there is, in fact, a daily empirical knowledge that cannot be dispensed with" (MAFFESOLI, 1988, p. 195). We also use Michel de Certeau; characteristics of Italian societies, by Luigi Biondi; stories of Italians in the Rio Grande do Sul, Luis de Boni, and Rovílio Costa; and considerations about region and regionality by José Clemente Pozenato. On the Italian migration and its press in Brazil, reflections by the historian Angelo Trento and documents cited in Italian government yearbooks.

\subsection{The Italian Immigration Process in Brazil}

First, it is necessary to present the reasons that made a large number of Italian immigrants come to Brazil. According to the Italian government, more than 1.8 million Italian immigrants and their descendants lived in Brazil between the end of the 19th century and the beginning of the 20th (1876 -

\footnotetext{
${ }^{2}$ The better translation for name La Staffetta Rio-Grandense can be the Rio-Grandense Messenger.

${ }^{3}$ The digital copy of the editions is in the historical collection of the Municipality of Caxias do Sul-RS. Available at: http://liquid.camaracaxias.rs.gov.br/portalliquid/Pasta/Documentos/3672.

${ }^{4}$ The year is important because of the celebrations for the fiftieth anniversary of Italian immigration in the Rio Grande do Sul (1875-1925).

${ }^{5}$ Michel Maffesoli is a French sociologist known internationally for popularizing the concept of the urban tribe (1995). Among many contributions, he built a workaround on the issue of community social connection and the prevalence of the imaginary in postmodern societies.
} 


\section{$1925)^{6}$.}

Many reasons made Brazil think of viable alternatives that would guarantee the workforce since the slave labor force ended in 1888. The economy of Brazil was based on slave labor on plantations. In the middle 19th century this labor force began to face extinction. First was the end of the slave trade and, later, in 1871, the enactment of the Free Womb Law, which freed the children of slaves born after it.

As a coincidence, the Brazilian economy started to count on the paid work of Italian immigrants who, because of the socioeconomic transformations in Italy, came to Brazil in search of jobs and new opportunities. Slaves, who would achieve their full freedom only in 1888, were replaced by Italian colonists in coffee plantations and also corn, wheat, and other agricultural products. In this context, Rio Grande do Sul state received colonists, mostly, from Tirol, Veneto, and Lombardia.

According to Boni and Costa (1982), between 1875 and 1914, 80 to 100 thousand Italians came to gaucho's soil. They also brought their language, habits, culture, and traditions, besides their experience in grape cultivation and wine production. Over the years, Brazilians incorporated many of these characteristics as an indelible mark Italian which multiplies proportionally, as the immigration flow increased in search of conquering their own space in the Rio Grande do Sul lands.

According to Pozenato (2005), each region defines the boundaries of its space not only in the physical aspect but also in the symbolic field. Therefore, the representation of the culture and identity of the Italians established the essence of their community ties, distinguishing them based on their identity and dialectal speech, facilitating their adaptation to the environment, in this case, a place different from their homeland. The process of acceptance and insertion of Italians in Brazilian cities brought advances in the economy and farming technology, in social development. Each colony had different aspects of how they organized their associations, leisure clubs, mutual aid associations ${ }^{7}$, and a means of communication accessible to all patricians: the newspaper.

\section{ITALIAN NEWSPAPERS IN BRAZIL AND RIO GRANDE DO SUL}

Italian-language publications in Brazil between the years of 1870 to 1940 because there is no record of some of them. As a fair guess, some researches think there might have been a number around 170 newspapers between 1880 and 1920 [...] in several territories in Brazil. In the Rio Grande do Sul state, there are an estimated 53 publications.

Many of the journals were written in dialect, a language through which their target audience could perceive the real sense of community belonging. Each publication, regardless of the theme or journalistic genre, was configured as a means of guiding, training immigrants through information, aiming at their adaptation to the new customs and habits, and exploring quotidian themes in their pages.

Each newspaper had both sides in the shared experience with the readers, editor, and reader. Two complementary elements that produced and reproduced their new life experiences, through the simplest gestures such as street conversations, religious events, and festivities. The newspapers became the mediators acting as symbolic affective bonds within the daily life of Brazilian cities that received Italian immigrants. In this sense, Trento (2013) states that several journals were published in a bilingual manner and cites as the most significant example. "La Staffetta Rio-Grandense in whichmonk Acchile Bernanrdi published in Veneto, and in chapters, his famous Vita e Storia de

\footnotetext{
${ }^{6}$ According to the Italian Government, between 1876 and 1925 - Brazilian Census of 1920 - the Brazilian population was $30,635,000$ inhabitants and had about 1,838,100 (6\%) immigrants from Italians and descendants. As originally described in the Statistical Yearbook of Italian Immigration -1876 to 1925: NelBrasilesopraunapopolazione di 30.635 milaabitanti in cifratonda (censimento del I920) solo il $40 \%$ è di razzabianca. Il $60 \%$, frameticci, mulatti, negri e indiani, èdirazzadi colore. Del primo nucleounbuonquindici per cento circaè italiano od oriundo italiano. Italianissimi, nelBrasile, alcuniinteriStatiatlantici. Sul totaledellapopolazione brasiliana, poi, lapercentuale italiana può, valutarsi sul $6 \%$ all'incirca"(Annuariostatisticodellaemigrazione italiana dal 1876 al 1925: connotiziesull'emigrazioneneglianni). Source: Italian Government, 1926.

${ }^{7}$ The development of Italian complementary care associations in Brazil was an important part of the migratory experience. Thousands of Italians were settled temporarily or permanently in Brazil since the last two decades of the imperial period. As in newly unified Italy (1861), Italians were also subject to active immigration processes alike those that were occurring in their origin regions before and through the emigration period (BIONDI, 2012, p.76).
} 
Nanneto Pipetta ${ }^{8}$ in the mid-1920s" (TRENTO, 2013, p. 16-17).

\section{LA STAFFETTA RIOGRANDENSE}

Published more than a century ago, La Staffetta Rio-Grandense, although with its name changed to Correio Rio-Grandense, is originally one of the most long-lived newspapers in Brazil. It begun aimed at the Italians who settled in the mountains of Rio Grande do Sul. Founded by Father Carmine Fasulo, parish priest of Santa Tereza parish, in the city of Caxias do Sul (RS). The newspaper began its activities in 1909 under the name "La Libertà" (Freedom), becoming a vehicle of evangelization by Capuchin Order (from the Catholic Church) in the Rio Grande do Sul.

The editorial line was not entirely on religious matters, but also agriculture, industry, commerce, social, and community development. Since the first editorial the newspaper made clear its link with the Catholic Church. After 1910, Father Giovanni Fronchetti acquired the newspaper and changed its name to "Il Colono Italiano" (The Italian settler) and moved to the city of Garibaldi (RS). Trying to be an informative tool for the colonists, it contributed a lot to the mountain region of Rio Grande do Sul consolidate its agricultural and livestock vocation.

The newspaper began to grow in the region, increasing the number of sessions and signed articles, following the daily rhythm of the life and history of the Italian colonists. In 1917, it became La Staffetta Rio-Grandense. The newspaper's popularity grew, giving the community a voice and ensuring space for genuine culture in sessions written, sometimes in Talian (Italian dialect).

When Brazil and Italy became enemies in World War II, it ended the newspaper connections, especially in the political, social, economic, and cultural fields. The use of the Italian language was forbidden inside Brazil and, below pressure, the newspaper changed its name, in 1941, to Correio RioGrandense, a name maintained until today.

In its early years, the newspaper worked as an instrument of integration by ensuring information to Italian colonists about the most diverse events, both in Brazil and in Italy. It is correct to assume that the key to this complex process (of countless alternatives) will only succeed by choosing appropriate methods in the transmission of each message. The procedure of La Staffetta with its readers presumed the fulfillment of steps within their quotidian experience, by strongly joining in their desires and needs and reflecting in their pages the result of this process of social sharing.

Thus, it is possible to realize that the journalism offered and given to the colonists had as proposition a horizontal line of communication, easy to read and to understand quotidian life, to guide, to integrate and passing on information, acting, therefore, as a promoter of inclusion to Italian immigrants.

An instrument of social communication prepared for information that can be classified into several categories within the scope of the public interest, from news coverage to the dissemination of popular culture produced in everyday life. By adopting the proper language in the colonists' regular life, the Talian' incorporated in the cultural customs the necessary values for a healthy coexistence between different groups that should cohabit in the same social space.

\subsection{The Role of the Newspaper in Everyday Life}

During 1925, the newspaper La Staffetta was a tool to expand social ties between the settlers regard to the legal issues of citizenship and affectivity. Including memory, and the quotidian experience that builds the community identity as a promoter of human development. In addition to reporting, the newspaper worked as a reference for the development of issues in the social sphere experienced.

\footnotetext{
${ }^{8}$ NanettoPipetta was a fictional character whose story described the life of the first Italian immigrants in the mountains of Rio Grande do Sul. La Vita e Storia de NanettoPipetta (Life and History of NanettoPipetta) is a narrative authored by monk AquilesBernardi, originally published as a serial by the newspaper La Staffetta Rio-Grandense between January 23, 1924, and February 18, 1925.

${ }^{9}$ Talian (or Brazilian Veneto) is a variant of the language spoken in the Veneto Region (northern Italy), which is still kept today, especially in the states of Rio Grande do Sul and Santa Catarina. When Italian immigrants began to arrive in Brazil, at the end of the 19th century, an official Italian language had not yet been established in Italy and the use of dialects was still prevalent. In 2014, IPHAN - National Historical and Artistic Heritage Institute included Talian in INLD - National Inventory of Linguistic Diversity, being officially certified by the Ministry of Culture of Brazil as a Brazilian cultural reference Decree No. 7,387, of December 9, 2010. Available at: http://portal.iphan.gov.br/pagina/detalhes/183. Accessed on: 15 Jun. 2016.
} 
It is common sense that quotidian life has the meaning of something that happens daily, is familiar to every day, and is of no extraordinary nature. However, it is also connected with something experienced and associated with a certain place at a certain time.The word also gets a meaning broadly used in the press when it designates what is published, gathering habitual and permanent actions that an individual, isolated or in a group, develops during the days.

Within the various possibilities that the word quotidian offers, our approach adopted as a corpus of research, the experience of immigrants and their relationship with the "new land", with the Italian press produced and published in Brazil as a guide. Newspapers have become an instrument of formation and representation of the group of Italian immigrants.

The feeling of daily reciprocity allows us to understand the importance and the role of newspapers not only as an information agent but as a tool, a channel at the service of the community, uniting journalism, and community reality. This relationship is the maximum value displayed in the reader's acceptance and based on trust and credibility.

The pages of La Staffetta became mirrors of quotidian life where, from their sessions ${ }^{10}$, the individual identified himself, influencing, and refeeding his constructive process. Something that is easily detected in the pages of the newspaper La Staffetta when approaching the harsh reality in which the new immigrants from Italy lived. A vehicle that established a relationship between the individual and his environment, based on a relationship of trust, making room for the community through a simple communication format, written in the colonists' mother tongue.

\subsection{The Quotidian Social Culture}

The difficulties of Italian immigrants also express their daily gaze towards the appropriation of their space, as transmitters of a foreign culture.

When analyzing the quotidian, we should also consider the French intellectual Michel de Certeau who dedicated part of his work to the study of the quotidian, through psychoanalysis, philosophy, and social sciences. In this sense, in his best-known book, The Invention of Quotidian, Certeau (1994) examines the different ways of understanding some matters less scientifically. The author teaches us in his method that "it is necessary to erase everyday linguistic practices (and the space of their tactics) so that scientific practices are exercised in their field" (CERTEAU, 1994, p. 81).

It is clear, therefore, the importance of insertion in everyday life as a fundamental component in the researcher overview, as an eyewitness, which enables him to have a more human view and more familiar to the broad view without the rationalist concern that requires the compartmentalization of knowledge.

A fragmentation that can mislead, a misinterpretation caused by the ignorance of cultural differences about the quotidian experiences as representative elements of a group, of a specific society segment. The quotidian is the history that belongs to each one of us, it is "that which binds us intimately, from the inside" (CERTEAU, 1994, p. 31).

The previous also acquire value in the conception of Maffesoli (1995a), for whom quotidian is a space of community sociability, which happens through communication. Each line of the journal reflects the construction of the facts indicating the intention to produce the art of making from the cultural experiences of the readers themselves, giving the necessary authenticity to the process of daily exchange. Whether for the thanks of a saved life:

Typography - We were pleased to see our esteemed friend Pietro Baruffi. He came to visit his old parents. We wish our brave advertiser prosperity, happiness, and long life in favor of the good press - The Newsroom (LA

\footnotetext{
${ }^{10}$ As an illustration, we mention some of the most significant sessions of the newspaper La Sataffetta Rio-Grandense and its daily functions: CorreiodelloStato (letters and information from readers), Beatiimorti (funeral communications), Per il Mondo (news about Italy and other countries), SezioneComerciale (commercial information), LetteraPastorale (Catholic Church affairs), Sfogliandoigiornali (miscellaneous news published in other newspapers), La Storia - La Maestradella vita (historical overview), Note Mediche (health), La e Qua (news from Brazil and Italy) and Vita e storia di NannetoPipetta (stories in the form of a serial written in Talian).
} 
STAFFETTA RIO-GRANDENSE, 1925b, p. 1 - our translation). ${ }^{11}$.

Or by communicating the passing of a loved one:

Nova Milano - On December 22, Candida Tolotti, daughter of Angelo Tolotti, died. Called Candi, the young woman was 32 years old. The poor thing, unfortunately, suffered from constant attacks. Her poor parents had not been able to leave her alone for a long time (LA STAFFETTA RIOGRANDENSE, 1925a - our translation). ${ }^{12}$.

The daily life of immigrant communities became a plural space because, of course, it was composed of the diversity of a culture brought by the various descendants, transmuted into new ones, based on the interactive process. The quotidian is written based on the new life of the immigrant who, in his heart, still kept other bonds (social, affective, family), born from his previous quotidian life, built-in his country of origin: "For the world - Italy - As spring approaches, thousands of pilgrims begin to flock to Rome to acquire the spiritual privileges and indulgences of the Holy Year. (LA STAFFETTA RIO-GRANDENSE, 1925 -c, p. 1 - our translation). ${ }^{13}$.

Our analysis found that the printed content surpassed in each of the articles in reporting the joys and sorrows, successes, and difficulties of the immigrant with the simplicity that compares to an everyday counselor when correlating the new Brazilian social practices with the prospect of realization of their dreams in the new land.

In the work "Contemplating the World", the first sentence written by Maffesoli reinforces the above relationship: "Dream and thought are closely linked, especially at times when societies dream of themselves" (MAFFESOLI, 1995-a, p. 11).

The concept of the quotidian, for Maffesoli, includes everything, respecting and valuing each space of land composed "by the products of the native soil, the regional dishes, the importance of the neighborhood or region as a small canton of the world in which we live" (MAFFESOLI, 2007, p. 66). Something that the text below shows, with the announcement of the arrival of special guests in the city of São Marcos / RS:

On March 28th, Saturday, at dusk, St. Marco's bells sounded cheerful. They were announcing to the community the arrival of Missionaries. The church was beautiful and tidy, a large pulpit was prepared for the expected large audience (LA STAFFETTA RIO-GRANDENSE, 1925-d, p. 2 - our translation). ${ }^{14}$.

Still, according to Maffesoli (2007), the resurgence of local languages and their daily rituals must also be included, such as the effect of the feeling of belonging that forms social relations. "The sense of dialogue as a social and natural environment in which each one is embedded. The type is a mold, which is the cause and effect of community culture "(MAFFESOLI, 2007, p. 62).

A good example of illustration can be found in the stories of the immigrant Nanneto Pipetta, written in dialect, reinforcing the importance of maintaining the language in everyday life. How to separate the adventures told by Nanetto, with his particular idioms, if not in his language, that understood by the readers who merged his Venetian dialect (brought with them from Italy) with Portuguese, generating the "Talian".

I use the speech so that they understand: life and story, etc. it is exactly how I tell you. Take a deep breath and sit down so you don't fall. I do not say by

\footnotetext{
${ }^{11}$ In the original: In tipografia- Abbiamoavutoilpiaceredirivedereilnostro bravo amico Pietro Baruffivenuto a visitare $\mathrm{i}$ suoivecchigenitori. Al nostro valente propagandista i più sinceri auguri di prosperità, felicita e vita lunga per bene della buona stampa - Redazione (LA STAFFETTA RIO-GRANDENSE,1925b, p.1).

${ }^{12}$ In translation, we use popular language for better understanding. In the original: Nova Milano - Il giorno 22 dicembre moriva improvvisamente Candida Tolotti, figlia di Angelo Tolotti. Candia conta l'età di 32 anni la poveretta per somma disgrazia era soggetta molto frequente a forti attacchhi. Giá da molti anni i poveri genitori dolenti non potevanos fidarsi a lasciarla sola (LA STAFFETTA RIO-GRANDENSE, 1925-a, p. 3).

${ }^{13}$ In the original: Per il mondo Italia: Coll'entar della primavera, cominciano ad affluire a migliaia di pellegrini che vanno a Roma guadagnare i privilegi spiritual e le indulgense dell'Anno Santo (LA STAFFETTA RIO-GRANDENSE, 1925c, p.1).

${ }^{14}$ In the original: S. Marco Il giorno 28 marzo, sabbato, in sul far della sera squillavano alegre le campane di S. arco, la annunzio alla popolazione dell'arrivo dei Missionari. La chiesa era bela, bem tenuta, um gran púlpito vi era preparato. (LA STAFFETTA RIO-GRANDENSE, 1925-d, p. 1).
} 
saying, but the story is genuine and those who read it will be happy and the others will not, because they do not know any of this. However, those who do not read the newspaper look for it fast because the story is about to begin ... Period and start (LA STAFFETTA RIO-GRANDENSE, 1924, p. 4, our translation). ${ }^{15}$.

The relationships that the individual maintains with his "lived world", as explained by Maffesoli (1995-b), is what matters for his recognition within the everyday universe. Just like the community involvement present in the pages of La Staffetta, where the purpose of the publication is to give immigrants a voice. It ends up sharing with other elements of society, Italian or not, in the conception of Maffesoli (2007- in the background) the pleasure of being together with the cause and effect of everyday life in the community.

Thus, by incorporating the collective experiences formed within its group, common sense, the present, and empathy begin to define the fundamental characteristics of the community aspect. "It is not, therefore, the reduction to the individual subject that is at issue in the resurgence of everyday life, but, quite the opposite: sociality" (MAFFESOLI, 1995-b, p. 176).

Many of the information printed has taken on the part of a warning, reinforcing La Staffetta's role with the interests of mostly agricultural immigrants and its use in the present:

Corn - This month the corn harvest begins. It is the right time to choose the corn cobs that will be used for the next sowing. This is called selection. A good selection begins by harvesting well-developed corn cobs, which are not too high and are thick at the base, so they will serve best (LA STAFFETTA RIOGRANDENSE, 1925e, p. 1 - our translation). ${ }^{16}$

When the French philosopher mentions that "daily complexity is permeated by concern for the present", he considers that it is not a static process, on the contrary, the culture produced in the quotidian is a continuous creative process that extends to adapt and legitimize "for the pleasure of the world and its fruits" (MAFFESOLI, 1995-b, p. 234).

\section{Final CONSIDERATIONS}

The quotidian experience shows its complexity from the plurality, in a universe that is constantly evolving, it is moved and driven by sharing. It is a result of the cooperation with individuals who experience discoveries every day. The result of any action is what makes it possible to expand the bonds from which community life is built. It stimulates the development of new potentials based on community cohesion. It is in the quotidian that social life takes place in a real and tangible way, where trades are carried out within an evolutionary process such as the history of the immigrants who drove their destiny when choosing Brazil to live.

In this sense, the role of Italian-language newspapers was crucial in identifying those daily values, ensuring the experience of any individual that can reflect and make decisions about what happens around them, contributing to the process of awareness and action. In other words, social transformations, built daily, acquire relevance on the pages of newspapers, expanding the existential space of community experience as a mirror that reflects each of its social transformations.

That is a relationship structured in heterogeneity as a result of global actions, built entirely, symbolic, and abstract, with varied intentions and intentions capable of perpetuating values, forged throughout history.

\footnotetext{
${ }^{15}$ Do parole per capirse. La vita e Storia etecetara etc... la xe próprio come ve ela conto. Tirarghene via saria come rotaria; e zontarghene no cade mia. No fasso par dire, ma la storia la xe genuína e quei che la lezerà resterá contenti e quealtri no savarà ngente de tuto sió. Però quei che no rissevesse el zornale che i varda de domandarlo presto perché la storia co la scominsia...punto e scominsio (LA STAFFETTA RIO-GRANDENSE, 1924, p. 1).

${ }^{16}$ In the original: In questomesesiraccoglieilgranturcoed è l'occasione di scegliere le spighecheserviranno per la futurasemina. Questo si chiamaselezione, uma buona selezione si principia cogliendo spighe dalle piante bene sviluppate, che non abbiano molta alteza e siano grossenella base, cosiresteranoall'allettamento. (LA STAFFETTA RIOGRANDENSE, 1925e, p. 1).
} 


\section{REFERÊNCIAS}

[1] BARDIN, Laurence. Análise de Conteúdo. Lisboa: Edições 70, 1977.

[2] BIONDI, Luigi. Mãos unidas, corações divididos. As sociedades italianas de socorro mútuo em São Paulo na Primeira República: sua formação, suas lutas, suas festas. Tempo, Niterói, v.18, n. 33, 2012. Disponível em: https://dx.doi.org/10.1590/S1413-77042012000200004. Acesso em: 15 jan. 2015.

[3] BONI, Luis de; COSTA, Rovílio. Os italianos do Rio Grande do Sul. 2. ed. Caxias do Sul: Universidade de Caxias do Sul, 1982.

[4] CERTEAU, Michel de. A invenção do cotidiano: artes de fazer. 12. ed. Petrópolis: Vozes,1994.

[5] GOVERNO ITALIANO. Annuariostatisticodellaemigrazione italiana dal 1876 al 1925. Roma: Commissariatogeneraledell'emigrazione,1926. Disponível em: https://ebilibio.istat.it/Annuari/TO001764 82Annuario_statistico_italiana_18761925.pdf. Acesso em: 2 jun. 2010.

[6] MAFFESOLI, Michel. O tempo das tribos. Rio de Janeiro: Forense Universitária, 1987.

[7] MAFFESOLI, Michel. O conhecimento comum. Compêndio de Sociologia Compreensiva. São Paulo: Brasiliense; 1988.

[8] MAFFESOLI, Michel. A contemplação do mundo. Porto Alegre: Artes e Ofícios, 1995-a.

[9] MAFFESOLI, Michel. O conhecimento do quotidiano: para uma sociologia da compreensão. Lisboa: Veja, 1995-b.

[10] MAFFESOLI, Michel. O ritmo da vida: variações sobre o imaginário pós-moderno. Rio de Janeiro: Record, 2007.

[11] POZENATO, José Clemente. Algumas considerações sobre região e regionalidade. In: Processos culturais: Reflexões sobre a dinâmica cultural. Caxias do Sul: Educs, 2005.

[12] TRENTO, Angelo. Do outro lado do Atlântico: um século de imigração italiana no Brasil. São Paulo, Nobel, 1989.

[13] TRENTO, Angelo. Imprensa italiana no Brasil. Séculos XIX e XX. São Carlos: EduFSCar, 2013.

[14] Jornais Consultados CORREIO RIO-GRANDENSE. Edição n. 5.532, Ano CVIII - Caxias do Sul - 8 de fevereiro de 2017, p. 10. Disponível em: http://www.correioriograndense.com.br. Acesso em: 30 abr. 2020.

[15] LA LIBERTÀ. Edição n. 1, 1909. Caxias do Sul/RS. Disponível em: http://liquid.camaracaxias. rs.gov. br/portalliquid/Pasta/Documentos/3672. Acesso em: 29 abr. 2020.

[16] LA STAFFETTA RIO-GRANDENSE. Edições pesquisadas:

[17] Edição n. 40, Ano XV, Garibaldi/RS, 23 jan 1924. Disponível em: http://liquid.camaracaxias.rs.gov. br/portalliquid/Pasta/Documentos/3672. Acesso em: 29 abr. 2020.

[18] Edição n. 36, Ano XVI, 7 jan. 1925a. Disponível em: http://liquid.camaracaxias.rs.gov.br/portalliquid /Pasta/Documentos/3672. Acesso em: 28 abr. 2020.

[19] Edição n. 50, Ano XVI, 4 fev. 1925b. Disponível em: http://liquid.camaracaxias.rs.gov.br/portalliquid /Pasta/Documentos/3672. Acesso em: 27 abr. 2020.

[20] Edição n. 40, Ano XVI, 18 mar.1925c. Disponível em: http://liquid.camaracaxias.rs.gov.br/portalliquid /Pasta/Documentos/3672. Acesso em: 25 abr. 2020.

[21] Edição n. 51, Ano XVI, 22 abr. 1925d. Disponível em: http://liquid.camaracaxias.rs.gov.br/portalliquid/ Pasta/Documentos/3672. Acesso em: 27 abr. 2020.

[22] Edição n. 9, Ano XVII, 1 jul. 1925e. Disponível em: http://liquid.camaracaxias.rs.gov.br/portalliquid /Pasta/Documentos/3672. Acesso em: 15 jan. 2017.

Citation: Beatriz DORNELLES, Ph. D. "The Quotidian of Italian Immigration in La Staffetta Rio-Grandense According to Michel Maffesoli" International Journal of Humanities Social Sciences and Education (IJHSSE), vol 7, no. 8, 2020, pp. 80-87. doi: https://doi.org/10.20431/2349-0381.0708009.

Copyright: (c) 2020 Authors. This is an open-access article distributed under the terms of the Creative Commons Attribution License, which permits unrestricted use, distribution, and reproduction in any medium, provided the original author and source are credited. 